\title{
Current approaches and future directions in the treatment of leprosy
}

This article was published in the following Dove Press journal:

Research and Reports in Tropical Medicine

I August 2012

Number of times this article has been viewed

\section{Sophie MWorobec}

Department of Dermatology, College of Medicine, University of Illinois at Chicago, Chicago, Illinois, USA
Correspondence: Sophie M.Worobec, MD Department of Dermatology, College of Medicine, University of Illinois at Chicago, Chicago, Illinois, USA Tel +l 3129966966

$\mathrm{Fax}+$ I 3129968638

Email sworobec@uic.edu
Abstract: This review surveys current treatments and future treatment trends in leprosy from a clinical perspective. The World Health Organization provides a multidrug treatment regimen that targets the Mycobacterium leprae bacillus which causes leprosy. Several investigational drugs are available for the treatment of drug-resistant $M$. leprae. Future directions in leprosy treatment will focus on: the molecular signaling mechanism $M$. leprae uses to avoid triggering an immune response; prospective studies of the side effects experienced during multiple-drug therapy; recognition of relapse rates post-completion of designated treatments; combating multidrug resistance; vaccine development; development of new diagnostic tests; and the implications of the recent discovery of a genetically distinct leprosy-causing bacillus, $\mathrm{Myco}$ bacterium lepromatosis.

Keywords: epidemiology, leprosy, Hansen's disease, multidrug resistance, multidrug therapy

\section{Introduction}

Leprosy (also known as Hansen's disease [HD], Hanseniasis, and elephantiasis grecorum) is a chronic, but curable, disease of humans, with skin, peripheral nerve, ocular, and upper respiratory tract mucosal involvement caused by infection with the pathogen Mycobacterium leprae. Macrophages and peripheral nerves (specifically the Schwann cells that ensheathe them in protective myelin) are the prime infection targets of this pathogen. Once established in tissue, M. leprae colonization and immunological reactions to its antigens can cause enlarged thickened peripheral nerves and sensory neuropathy, cutaneous lesions, damage of multiple other tissues, disfigurement, and severe disability. Leprosy is an ancient disease; a human skeleton showing bone erosion consistent with leprosy dates back 4000 years. ${ }^{1}$

\section{Transmission}

M. leprae is a nonmotile, Gram-positive, acid- and alcohol-fast, thick-walled bacillus; that is, a small, rod-shaped bacterium. It is an "obligate intracellular parasite"2 that cannot grow and divide outside an animal host. In vivo, it grows best at a temperature range of $27^{\circ} \mathrm{C}-30^{\circ} \mathrm{C}\left(81-86^{\circ} \mathrm{F}\right)$, which is below the core temperature of humans. ${ }^{3}$

M. leprae can remain viable for up to 5 months in the environment. ${ }^{4}$ Although capable of withstanding a single freeze-thaw cycle, it loses viability with subsequent freeze-thaw cycles so that it does not survive four. ${ }^{5}$ It divides extremely slowly compared with other bacteria (12-13 days). Because of this slow growth, the incubation period in humans is long: a minimum of 2 to 3 years, with the average incubation time between 5 and 7 years, although it can be as long as decades. ${ }^{6}$ Because of the long and 
variable incubation period of the disease, our understanding of its transmission remains incomplete. Modes of transmission could occur by: 1) exposure to nasal or oral secretions of patients harboring bacilli; 2) skin-to-skin contact; 3) congenital transmission; ${ }^{7}$ 4) dermal inoculation via tattoo needles; ${ }^{8}$ $5)$ contact with infected soil or wetlands or sphagnum moss; and 6) exposure to insect or arthropod vectors. ${ }^{9}$

\section{Epidemiology}

Fewer than 1 in 20 people (5\%) exposed to M. leprae develop clinical disease. Host cell-mediated resistance determines whether an individual will develop paucibacillary (PB, high resistance) or multibacillary ( $\mathrm{MB}$, low resistance) disease. For PB disease, the incubation period is up to 5 years, and for MB disease it is 20 years or longer. ${ }^{6}$

The global registered prevalence of leprosy cases at the beginning of 2011stood at 192,246 cases, which is less than the 228,474 new cases detected in $2010 .{ }^{10}$ The reason for the disparity is that some new cases complete their treatment within the year and get removed from the registry. Figure 1 shows how new reported leprosy cases are distributed among various countries. Several countries (India, Brazil, Nepal, and Bhutan) continue to experience new leprosy cases per 100,000 inhabitants at higher rates than most other countries. ${ }^{10}$
Even in countries with relatively low rates of new leprosy cases, endemic regions exist and tend to persist. In the United States, leprosy is rare, with 161 new cases of leprosy reported in 2009, and 169 new cases reported in 2010. The majority of new US cases are traceable to prior exposure from living or working abroad in leprosy-endemic areas. However, about a third of US patients appear to have acquired leprosy from local sources. In New York City, three cases of leprosy have been diagnosed in patients who had never been outside the US, signifying the emergence of a new endemic area. ${ }^{11}$ In the southern US, a genotype comparison of $M$. leprae in human patients and nine-banded armadillos strongly implicates armadillos as the source of infection: "Leprosy appears to be a zoonosis in the southern United States." 12

Elsewhere in the world, humans are the only known reservoir for $M$. leprae. Household contact with a person with untreated $\mathrm{MB}$ disease in an endemic area carries up to a $10 \%$ risk of eventually contracting the disease, with children being at greater risk. ${ }^{13}$

Leprosy, being a worldwide disease, has been the target of a World Health Organization (WHO) multiple-drug therapy campaign, with the support of private foundations and pharmaceutical companies, to eliminate it as a national public health problem in member countries.

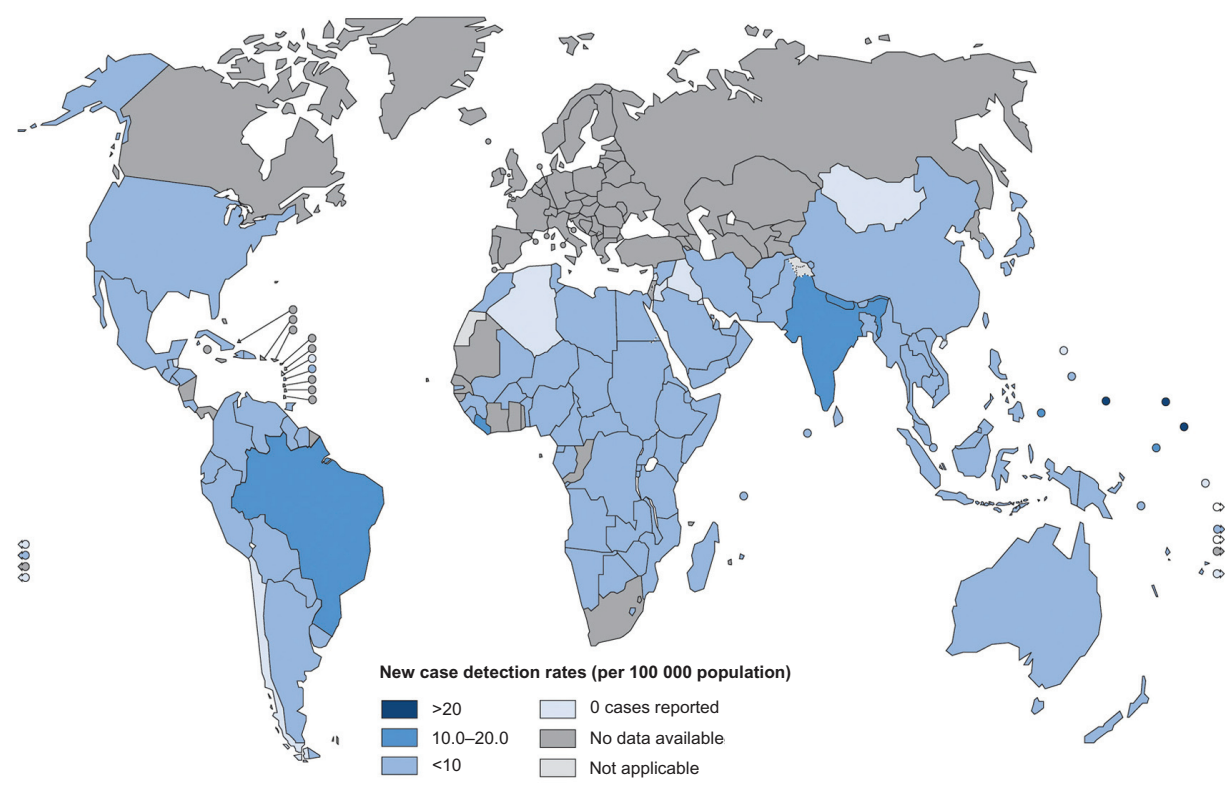

Data Source: World Health Organization
Map Production: Control of Neglected Map Production: Control
Tropical Diseases (NTD)
Wowid Heath Wopld Health Organization
๑ WHO 2011. All rights reserve

Figure I Leprosy new case detection rates, as of beginning January $201 \mathrm{I}$.

Note: () 20II, World Health Organization. Reproduced with permission from Leprosy Today [webpage on the Internet]. Geneva: World Health Organization; c20I2 [cited 2012 May 28]. Available from: http://www.who.int/lep/en/. Accessed February 22, 2012.10

Abbreviations: WHO, World Health Organization. 
In 2012, the WHO summarized the campaign's progress: "Of the 122 countries considered endemic for leprosy, 119 have eliminated the disease as a public-health problem (defined as achieving a prevalence rate of less than 1 case / 10,000 population)." ${ }^{14}$ The 192,246 cases known to remain are confined mostly to 17 countries reporting more than 1000 new cases annually. This number represents a greater than $90 \%$ reduction in the number of annual cases reported since 1985, a result of timely case finding and multidrug treatment therapy. ${ }^{14}$

\section{Leprosy diagnosis and classification systems}

A clinical diagnosis of leprosy is based on finding consistent skin lesions with associated sensory loss, with or without associated thickened nerves. Purely neural disease without clinical evidence of skin lesions has been called "pure or primary neuritic" and can be difficult to diagnose. ${ }^{15,16}$ Its incidence has been reported to be as low as $1 \%$, and as high as $16 \%$ of leprosy cases in endemic regions. ${ }^{16}$

\section{Classification systems evolution}

Different classifications systems have been proposed based on clinical (cutaneous, neural) findings, histological findings, and the immunological spectrum of resistance to the disease.
Sushrata Samhita, an Indian medical treatise, written about $600 \mathrm{BCE}$, is the first recognized record of three clinical forms of leprosy: purely neural, cutaneous with sensory loss, and cutaneous lesions with ulceration. ${ }^{15}$ Throughout the mid-19th century, researchers saw fit to devise idiosyncratic classification systems. The Manila Classification of 1931 was the first internationally recognized classification system, dividing leprosy into three types: cutaneous, neural, and mixed. Afterwards, changes to the classification of leprosy occurred at international meetings in Cairo (1938), Rio de Janeiro (1946), Havana (1948), and Madrid (1953). The first meeting of the WHO Expert Committee on Leprosy in 1952 recommended classifying leprosy into four groups: lepromatous, tuberculoid, borderline, and indeterminate, classifications that have persisted, with slight modification, to the present. ${ }^{15}$

\section{Ridley-Jopling classification}

In medical research centers with requisite analytic capability, the "gold standard" for a diagnosis of leprosy is histological confirmation with both hematoxylin-eosin and Fite-Faraco stains being carried out to recognize granulomatous disease and the presence of acid-fast bacteria. ${ }^{17,18}$ The acid-fastness of M. leprae arises from the presence of waxy mycolic acid in its cell wall. Viable bacteria take up stain but as they degenerate,

Table I The Ridley-Jopling classification of leprosy based on immune response ${ }^{18,21-23}$

\begin{tabular}{|c|c|c|c|c|c|}
\hline $\begin{array}{l}\text { Immune } \\
\text { response }\end{array}$ & High resistance & & Unstable resistance & & $\begin{array}{l}\text { Little or no } \\
\text { resistance }\end{array}$ \\
\hline Clinical spectrum & $\begin{array}{l}\text { Polar tuberculoid } \\
\text { (TT) }\end{array}$ & $\begin{array}{l}\text { Borderline tuberculoid } \\
\text { (BT) }\end{array}$ & $\begin{array}{l}\text { Borderline borderline } \\
\text { (BB) }\end{array}$ & $\begin{array}{l}\text { Borderline lepromatous } \\
\text { (BL) }\end{array}$ & $\begin{array}{l}\text { Lepromatous } \\
\text { (LL subpolar and } \\
\text { polar) }\end{array}$ \\
\hline $\begin{array}{l}\text { Number } \\
\text { of skin lesions }\end{array}$ & Few, usually single & Few & Few or many & Many & Many \\
\hline $\begin{array}{l}\text { Bacillary } \\
\text { load }\end{array}$ & 0 or, rarely, I+ & $1+$ & $2+$ & $3+$ & $4+$ \\
\hline Lepromin reaction & Positive & Positive & $\begin{array}{l}\text { Positive, doubtful, } \\
\text { or no response }\end{array}$ & Doubtful or no response & No response \\
\hline Histology & $\begin{array}{l}\text { Epithelioid granulomas } \\
\text { ringed by numerous } \\
\text { lymphocytes found } \\
\text { around dermal } \\
\text { appendages and nerves } \\
\text { in both papillary and } \\
\text { reticular dermis; } \\
\text { extending up to the } \\
\text { epidermis. Caseation } \\
\text { necrosis may occur. } \\
\text { Nerve edema, infiltration } \\
\text { by acid-fast bacilli (AFB), } \\
\text { or destruction. }\end{array}$ & $\begin{array}{l}\text { Epithelioid granulomas } \\
\text { with a moderate number } \\
\text { of lymphocytes. Langhans } \\
\text { giant cells can be present. } \\
\text { Rare infiltration of } \\
\text { subepidermal zone. Nerve } \\
\text { edema, infiltration by AFB, } \\
\text { or destruction. }\end{array}$ & $\begin{array}{l}\text { Granulomas consist of } \\
\text { foamy macrophages. } \\
\text { Number of lymphocytes } \\
\text { in granulomas is generally } \\
\text { less but varies. Langhans } \\
\text { cells absent. Dermal } \\
\text { nerves show Schwann cell } \\
\text { proliferation; infiltration } \\
\text { by AFB, lymphocytes, } \\
\text { and macrophages. }\end{array}$ & $\begin{array}{l}\text { Increasing histiocytes and } \\
\text { fewer epithelioid cells } \\
\text { and lymphocytes. Foamy } \\
\text { macrophages, lipid-laden } \\
\text { granulomas with a Grenz } \\
\text { zone (clear subepidermal } \\
\text { zone) present. Globi } \\
\text { (macrophages containing } \\
\text { bacilli in large clumps) can } \\
\text { be present but large globi } \\
\text { are not. Nerve bundles } \\
\text { damaged. }\end{array}$ & $\begin{array}{l}\text { Massive } \\
\text { granulomas or } \\
\text { diffuse sheets of } \\
\text { foamy lipid-laden } \\
\text { granulomas with } \\
\text { thin Grenz } \\
\text { zone present. } \\
\text { Multiple and } \\
\text { even large } \\
\text { multinucleate } \\
\text { globi occur. } \\
\text { Nerve bundles } \\
\text { damaged. }\end{array}$ \\
\hline
\end{tabular}


stain irregularly and ultimately lose acid-fastness. ${ }^{19}$ Bacteria can be difficult to demonstrate, especially in indeterminate and PB disease, which can lead to false negative diagnoses. ${ }^{20}$

The earliest clinically apparent leprosy lesion is that of indeterminate leprosy which may be self-healing. The RidleyJopling Classification (Table 1), introduced in $1966^{21}$ and still valid, divides determinate leprosy along a continuum according to immunologic response. At one pole, patients with tuberculoid leprosy are able to restrict the growth of the pathogen and their skin lesions are characterized by a predominance of CD4+ T cells and type 1 cytokines including interleukin 2 and interferon $\gamma$ (Th1 type response). At the opposite pole, patients with lepromatous leprosy are unable to contain the infection and their skin lesions have a high bacillary load, characterized by a predominance of CD8+ T cells and type 2 cytokines including interleukins 4 and 10 (Th2 type response). This classification system is useful for precise diagnosis and follow-up of clinical disease over long periods of time, ${ }^{22}$ and depends on having histological confirmation of clinical findings.

\section{WHO simplified classification}

Prior to 1998, the WHO guidelines required trained field workers in many endemic countries to make a diagnosis of leprosy and then confirm the diagnosis by slit skin smears taken from lesions and from cooler areas of the body (earlobes, elbows, and knees). ${ }^{\text {a }}$ These slit skin smears were examined for acid-fast bacilli (AFB) and the patients were considered $P B$ if the smears were negative and the patient had five or fewer skin lesions, and MB if the smears were positive for AFB. In 1998, the WHO eliminated requiring slit skin smear examinations for AFB as well as any neurological assessment, ${ }^{24}$ positing that health workers under field conditions could diagnose leprosy from clinical signs alone, ensuring early treatment and averting disability. ${ }^{25}$ The WHO also feared that it was unethical to require field personnel to carry out routine slit skin smears under conditions of risk of exposure to hepatitis or human immunodeficiency virus. ${ }^{26}$ The resulting simplified, but less accurate clinical classification system for field programs has remained unchanged until the present (Table 2).

The downside of applying the WHO classification without histological confirmation is that it can misdiagnose patients as having leprosy when they do not, or classify patients with MB disease as having PB disease. For example, in one study in India, investigators supplemented the clinical classification

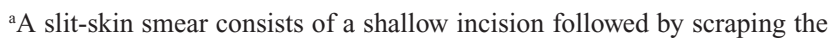
inner wound surface with a blade held at a right angle to the incision. Tissue fluid and dermal tissue are obtained from the scraping and transferred from the blade to a clean microscopic slide, where a circular smear is made.
Table 2 World Health Organization simplified leprosy classification as of $2012^{27}$

\begin{tabular}{ll}
\hline SLPB & Paucibacillary single lesion leprosy (one skin lesion present), \\
PB & Paucibacillary leprosy (two to five skin lesions), and \\
MB & Multibacillary leprosy (more than five skin lesions).
\end{tabular}

of leprosy with skin smears and skin and nerve biopsies. Of 21 patients presenting with enlarged nerves, the WHO clinical classification alone gave a diagnosis of PB leprosy. However upon histopathological examination of skin and nerves, four (19\%) showed no histopathological evidence of leprosy, and ten (48\%) showed borderline lepromatous (that is, MB) disease. ${ }^{28}$

Despite new cases of leprosy (see Figure 2) as diagnosed by the WHO classification dropping dramatically from levels reported a decade earlier, leprosy stubbornly persists in endemic areas. The WHO is now deciding whether "development of methods to increase the specificity of diagnosis, notably for PB leprosy, will enhance the elimination strategy," ${ }^{29}$ signaling a return to more stringent diagnostic criteria.

\section{M. leprae genome biology}

The genome of the M. leprae (from a patient in Tamil Nadu, India) was completely sequenced in $2001 .^{2}$ The genome was found to be largely inactive, with only $49.5 \%$ being protein coding and having 1614 protein coding genes compared to the Mycobacterium tuberculosis genome being $91 \%$ protein coding and having 4000 protein coding genes. This $M$. leprae TN genome also had 50 genes that encode 50 stable ribonucleic acids (RNAs). It is the smallest genome and the most adenine- and thymine- $(\mathrm{A}+\mathrm{T})$-rich genome of any known mycobacterium. The fact that almost $50 \%$ of the genome is composed of ostensibly inactive non-coding pseudogenes may account for its slow division time and for its lack of viability in vitro. Genetic sequencing of four different strains (TN; Br4923 from Brazil; Thai53 from Thailand;

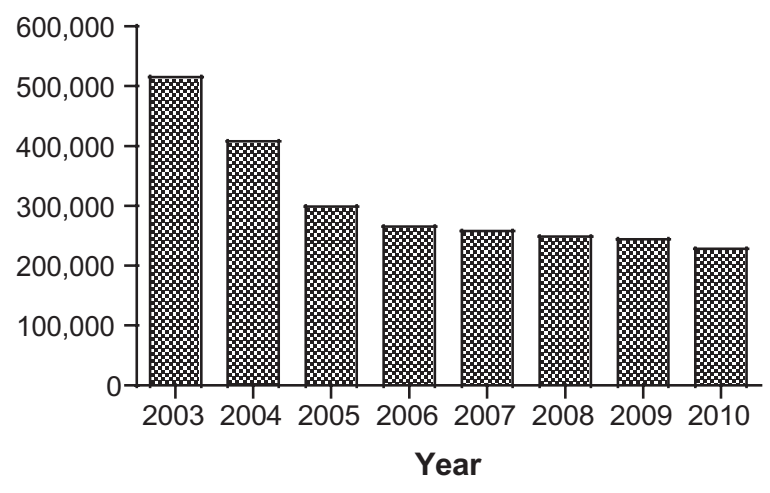

Figure $2 \mathrm{New}$ cases of leprosy worldwide. 
and NHDP63 from the US) of the M. leprae genome has shown a worldwide (99.995\% identical) conservation of its genome with few new pseudogenes and 215 polymorphic sites. Mapping of these polymorphisms further revealed 16 single nucleotide polymorphism subtypes or strains with strong geographical associations that allowed researchers to trace the evolutionary spread of $M$. leprae from an origin in East Africa throughout the rest of the world. ${ }^{30}$

$M$. leprae's reduced ability to survive at temperatures above $33{ }^{\circ} \mathrm{C}$, compared with its distant cousin, M. tuberculosis, was found through genetic sequencing to arise from $M$. leprae's having only $68 \%$ of the genes active in M. tuberculosis to form heat shock response proteins. These genes, in $M$. leprae, are either absent or present as pseudogenes. $M$. leprae specifically lacks a key signaling gene that induces a promoter sequence to form heat shock response proteins. ${ }^{31}$

Researchers have mixed opinions on the benefit of human gene sequencing "molecular epidemiology" studies for disease treatment. The optimistic view is that "biomarkers for reactional stages could aid in early diagnosis, efficient treatment, prevention of neurological complications, and predictions of predisposition to reactional stages." 32

\section{Antimicrobial chemotherapy}

In 1933, Sister Hilary Ross and Dr George Fite started a laboratory for drug testing in Carville, Louisiana, USA, under the auspices of the US Public Health Service. From 1940 to 1947, Dr Guy Henry Faget's team efforts at Carville proved the efficacy of sulfone medications (promin, dapsone) for the treatment of leprosy. However, by 1953, the first dapsoneresistant cases were being reported. After 30 years of dapsone monotherapy to treat leprosy in the US and worldwide, sulfone-resistant $M$. leprae became widespread. ${ }^{33}$

Once the mouse footpad in vivo culture model was developed, the molecular basis for dapsone resistance could be elucidated. As reviewed by Williams and Gillis, ${ }^{34}$ dapsone, a synthetic sulfone, targets dihydropteroate synthase, an enzyme necessary for bacteria's folate biosynthesis pathway. Missense mutations within either of two areas in each of $M$. leprae's codons 53 and 55 of the sulfone resistancedetermining region result in dapsone-resistant $M$. leprae.

M. leprae becomes drug-resistant through adaptive evolution. Untreated $\mathrm{MB}$ patients can harbor $>10^{11}$ $M$. leprae bacilli. The frequency of occurrence of dapsoneresistant mutants is $\sim 10^{-6}$, so a patient could have 100,000 dapsone-resistant bacilli that survive dapsone treatment, capable of growing and dividing, increasing over time to the same $M$. leprae count prior to treatment. ${ }^{34}$ The infected individual then sheds dapsone-resistant $M$. leprae to the environment so that others who come in contact can become infected.

Dapsone-resistant mutant $M$. leprae isolates can be identified by polymerase chain reaction (PCR) deoxyribonucleic acid (DNA) amplification and analysis of specific DNA fragments taken from skin biopsy fragments. ${ }^{17,35,36}$

Also at Carville, Dr Robert Jacobson headed research into drug resistance and helped develop multiple-drug therapy (MDT) (which now includes dapsone, rifampin, ofloxacin, clofazimine, and minocycline), leading to the US Public Health Service recommending it in 1981, followed by the WHO adoption of MDT in $1982 .{ }^{18}$ Although there have been other MDT protocols, ${ }^{37}$ this paper will only discuss the widely used WHO protocols, and the US Public Health Service National Hansen's Disease Program protocols.

\section{WHO treatment guidelines}

The WHO's MDT regimen of 2012 is shown in Table 3 (adults) and Table 4 (children).

Compliance with treatment is a major problem: published noncompliance rates range from $13-68 \%$ and poor compliance has been linked to treatment failure, persistent infectious sources and poor therapeutic success. Use of a urine test for dapsone monitoring during clinic visits was found not only to increase treatment compliance, but also improved clinical response in the compliant subgroup versus poorer therapeutic response in the consistently noncompliant patients. ${ }^{40}$

\section{WHO chemotherapy alternatives in multidrug therapy}

From retrospective studies, side effects of the WHO MDT were found to range from gastrointestinal distress to hemolytic anemia and, rarely, dapsone hypersensitivity syndrome (which can be fatal). ${ }^{41}$ Side effects can be important, especially when they lead to an interruption of therapy, or even discontinuation of a drug. Interruptions of therapy due to adverse side effects may be more common than investigators realize, suggesting a need for prospective studies to improve our understanding of the incidence and severity of these side effects. ${ }^{41}$

For patients that don't tolerate some of the drugs in the standard MDT, the WHO has provided guidance for alternative MDT regimens, to be administered under direct supervision in a referral center. For example, to replace rifampin in adult MB patients, the WHO suggests daily administration 
Table 3 World Health Organization recommended multidrug treatment adult ${ }^{\mathrm{a}}$ regimen for new cases of leprosy ${ }^{38,39}$

\begin{tabular}{|c|c|c|}
\hline \multirow[t]{5}{*}{ IA } & \multicolumn{2}{|c|}{ SLPB (single skin lesion paucibacillary) } \\
\hline & \multicolumn{2}{|c|}{ A single dose of: } \\
\hline & Rifampicin & $600 \mathrm{mg}$ \\
\hline & Ofloxacin & $400 \mathrm{mg}$ \\
\hline & Minocycline & $100 \mathrm{mg}$ \\
\hline \multirow[t]{4}{*}{ IB } & \multicolumn{2}{|c|}{ PB (multiple skin lesion paucibacillary) } \\
\hline & Rifampicin & $600 \mathrm{mg}$ once per month, on day I \\
\hline & Dapsone & $100 \mathrm{mg}$ daily \\
\hline & \multicolumn{2}{|c|}{ Duration of regimen $=6$ months } \\
\hline \multirow[t]{6}{*}{2} & \multicolumn{2}{|c|}{ MB (multibacillary leprosy) } \\
\hline & Rifampin & $600 \mathrm{mg}$ once per month, on day I \\
\hline & Dapsone & $100 \mathrm{mg}$ daily \\
\hline & Clofazimine & $300 \mathrm{mg}$ once per month, on day I \\
\hline & Clofazimine & 50 mg daily, after day I \\
\hline & \multicolumn{2}{|c|}{ Duration of regimen $=12$ months } \\
\hline
\end{tabular}

Notes: ${ }^{a}$ Based on adult 50-70 kg ( $\left.110-155 \mathrm{lbs}\right)$. Not recommended in the US, and

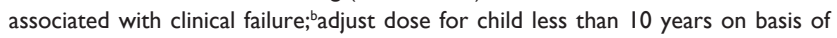
body weight: rifampin $10 \mathrm{mg} / \mathrm{kg}$ monthly and dapsone $2 \mathrm{mg} / \mathrm{kg}$ daily; clofazimine can be spaced out as required. The WHO states that "a patient with a high $\mathrm{BI}$ [bacterial index] may rarely need to be treated for longer than 12 months. Only specialists at referral centers should make this decision." ${ }^{\prime 4}$

of clofazimine $50 \mathrm{mg}$, ofloxacin $400 \mathrm{mg}$ and minocycline $100 \mathrm{mg}$ for $6 \mathrm{months}$; followed by daily clofazimine $50 \mathrm{mg}$, with either minocycline $100 \mathrm{mg}$ or ofloxacin $400 \mathrm{mg}$ for at least 18 months. Patients who cannot take clofazimine can be treated with a combination of $600 \mathrm{mg}$ rifampicin, $400 \mathrm{mg}$ ofloxacin, and $100 \mathrm{mg}$ minocycline (ROM) given once a month for 24 months. ${ }^{26}$

If the toxic effects of dapsone are severe, in PB patients it can be replaced by clofazimine in the same dosage as that used for MB patients but given for 6 months only. In MB patients, dapsone should be stopped and treatment continued with rifampicin and clofazimine in the standard dosage for 12 months. ${ }^{26}$

\section{National Hansen's Disease Program, United States treatment guidelines}

In the US, the National Hansen's Disease Program (NHDP) recognizes the $\mathrm{WHO}$ classification of leprosy as $\mathrm{MB}$ or $\mathrm{PB}$ (with six or more lesions representing MB HD, and five or fewer, PB HD) but provides treatment guidelines which are longer than the WHO ones. ${ }^{42}$ Further, the NHDP recommendations for treatment (Table 5) differ from those of the WHO for the treatment of children, and also in the use of clofazimine, which in the US is considered an investigational drug.

In the US, the MDT regimen for PB (TT or BT) leprosy comprises 12 months of dapsone and rifampin, but excludes
Table 4 World Health Organization recommended multidrug treatment child ${ }^{a}$ regimen for new cases of leprosy 38,39

\begin{tabular}{|c|c|c|}
\hline \multirow[t]{5}{*}{ IA } & \multicolumn{2}{|c|}{ SLPB (single skin lesion paucibacillary) } \\
\hline & \multicolumn{2}{|c|}{ A single dose of: } \\
\hline & Rifampin & $300 \mathrm{mg}$ \\
\hline & Ofloxacin & $200 \mathrm{mg}$ \\
\hline & Minocycline & $50 \mathrm{mg}$ \\
\hline \multirow[t]{4}{*}{ IB } & \multicolumn{2}{|c|}{ PB (multiple skin lesions paucibacillary) ${ }^{\mathrm{b}}$} \\
\hline & Rifampin & $450 \mathrm{mg}$ once per month, on day I \\
\hline & Dapsone & $50 \mathrm{mg}$ daily \\
\hline & \multicolumn{2}{|c|}{ Duration of regimen $=6$ months } \\
\hline 2 & \multicolumn{2}{|c|}{ MB (multibacillary leprosy) ${ }^{c}$} \\
\hline & Rifampin & $450 \mathrm{mg}$ once per month, on day I \\
\hline & Dapsone: & $50 \mathrm{mg}$ daily \\
\hline & Clofazimine & I50 mg once per month, on day I \\
\hline & Clofazimine & $50 \mathrm{mg}$ every other day \\
\hline & \multicolumn{2}{|c|}{ Duration of regimen $=12$ months } \\
\hline
\end{tabular}

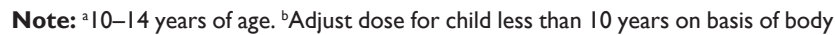
weight: rifampin $10 \mathrm{mg} / \mathrm{kg}$ monthly and dapsone $2 \mathrm{mg} / \mathrm{kg}$ daily. 'Adjust dose for child less than 10 years on basis of body weight: rifampin $10 \mathrm{mg} / \mathrm{kg}$ monthly, clofazimine $1 \mathrm{mg} / \mathrm{kg}$ semi-daily and $6 \mathrm{mg} / \mathrm{kg}$ monthly, and dapsone $2 \mathrm{mg} / \mathrm{kg}$ daily. The standard child blister pack may be broken up so that the appropriate dose is given to children under 10 years of age.

both ofloxacin and minocycline recommended by the WHO single-lesion PB treatment guideline, as well as the single dose WHO recommendation for single-lesion PB treatment.

In patients with preexisting or subsequent anemia, dapsone dosing should be lowered to $50 \mathrm{mg}$, the minimally effective level. Clofazimine, $50 \mathrm{mg} /$ day for 1 year, no longer commercially available in the US, is provided by the NHDP as an investigational new drug for treatment of US adult patients.

According to NHDP guidelines, use of this three-agent regimen for patients with $\mathrm{MB}$ (LL, BL, BB) leprosy in the

Table 5 US National Hansen's Disease Program (NHDP) treatment guidelines ${ }^{42}$

\begin{tabular}{|c|c|c|c|}
\hline $\begin{array}{l}\text { WHO } \\
\text { classification }\end{array}$ & $\begin{array}{l}\text { NHDP } \\
\text { treatment }\end{array}$ & Dose & Treatment duration \\
\hline $\begin{array}{l}\text { Single-lesion } \\
\text { paucibacillary }\end{array}$ & $\begin{array}{l}\text { Dapsone } \\
\text { Rifampin }\end{array}$ & $\begin{array}{l}100 \mathrm{mg} / \text { day } \\
600 \mathrm{mg} / \text { day }\end{array}$ & $\begin{array}{l}12 \text { months, } \\
\text { and then therapy } \\
\text { discontinued }\end{array}$ \\
\hline Paucibacillary & $\begin{array}{l}\text { Dapsone } \\
\text { Rifampin }\end{array}$ & $\begin{array}{l}100 \mathrm{mg} / \text { day } \\
600 \mathrm{mg} / \text { day }\end{array}$ & $\begin{array}{l}12 \text { months, and then } \\
\text { therapy discontinued }\end{array}$ \\
\hline Multibacillary & $\begin{array}{l}\text { Dapsone } \\
\text { Rifampin } \\
\text { Clofazimine }\end{array}$ & $\begin{array}{l}100 \mathrm{mg} / \text { day } \\
600 \mathrm{mg} / \text { day } \\
50 \mathrm{mg} / \text { day }\end{array}$ & $\begin{array}{l}24 \text { months, and then } \\
\text { therapy discontinued }\end{array}$ \\
\hline
\end{tabular}

Notes: ${ }^{\text {TT }}$ The recommended durations of treatment are sufficient, even though large numbers of dead bacilli may remain in the tissues for several years, before they are eliminated by physiological processes. There is no evidence that additional, prolonged treatment hastens the elimination of these dead organisms. 
US is extended to 24 months, whereas the WHO recommends its regimen for 12 months (see Tables 3 and 4).

In the US, where cost is not an overriding factor in treatment regimen, the NHDP also recommends the following alternative anti-microbial agents:

- Minocycline, $100 \mathrm{mg}$ daily, can substitute for dapsone in individuals who do not tolerate dapsone. It can also be used instead of clofazimine, although evidence of the efficacy of its anti-inflammatory activity against Type 2 reactions (discussed in the next section) is not as substantial as the evidence for clofazimine. Minocycline should not be used in children or during pregnancy because it may deposit in tooth enamel and discolor teeth. ${ }^{42}$

- Clarithromycin, $500 \mathrm{mg}$ daily, is also effective against $M$. leprae, and can be used as a substitute for any of the other drugs in a multiple-drug regimen. In children, this drug is recommended in place of clofazimine, as clofazimine cannot be used in children in the United States.

- Ofloxacin, $400 \mathrm{mg}$ daily, may also be used in place of clofazimine, for adults. This drug is not, however, recommended for children.

For immunologically compromised patients, these protocols may be modified, and consultation with the NHDP is recommended. In the United States, the occurrence of leprosy in children is rare. The NHDP strongly recommends contacting the NHDP for management of leprosy in children.

Five-year follow-up every 6 months is recommended in the United States for PB cases, and 10-year follow-up at 6-month intervals for MB patients. Examination of household and family contacts at time of diagnosis and annually is also recommended.

Patient and accompanying person(s) education about the disease and reactional states is vital. Adjunctive therapies target prevention of ocular, neurological, and orthopedic impairments, providing occupational and physical therapy and cosmetic surgery as needed, such as for nasal reconstruction and replacement of hair at lateral eyebrows.

\section{Leprosy reactions}

About half of leprosy patients experience acute episodes of destructive inflammatory reactions caused by their immune response to bacterial antigens released when bacilli die. Reactions may occur before, during and even after completion of therapy. It is very important to continue antimicrobial therapy while giving immunosuppressive therapy during these reactional states. Most reactions fall under two cat- egories: Reversal (also known as Type 1, RR, or T1R), and erythema nodosum leprosum (also known as Type 2, ENL, or T2R). Although distinct conditions, they may arise at different times in the same patient. Leprosy reactions can result in permanent loss of nerve function; that is, a reduction in sensory or motor function.

\section{Reversal reaction}

Reversal reactions (T1Rs) are a delayed hypersensitivity immune system response that develops after exposure to an antigen that the immune system recognizes as foreign. T1Rs in leprosy occur most often during the first 6 months of MDT in patients with either PB or MB leprosy, but more commonly in $\mathrm{MB} .{ }^{43}$ Clinically, a T1R is characterized by inflammation within skin lesions or within nerves or both. A pre-existing skin lesion may abruptly become edematous and erythematous, which can lead to ulceration. T1Rs can reoccur, which increases the risk of nerve damage.

Treatment of T1Rs consists of anti-inflammatory drugs such as corticosteroids, aimed at preventing tissue destruction and nerve damage. The drug interaction between prednisone and rifampin is significant, and rifampin dosage should decrease from $600 \mathrm{mg}$ /day to $600 \mathrm{mg} / \mathrm{month}$ with the addition of corticosteroid therapy. ${ }^{44}$

\section{Erythema nodosum leprosum}

Erythema nodosum leprosum (ENL) occurs in BL and LL leprosy and is a serious and often prolonged immunological reaction. It is mediated by circulating immune complexes, and involves the release of very high levels of tumor necrosis factor (TNF- $\alpha$ ) by peripheral blood monocytes.

ENL can be treated with high-dose prednisone, which quickly suppresses the inflammatory state. However, prolonged prednisone use is associated with numerous metabolic side effects, cataracts, hypertension, diabetes mellitus, and aseptic hip necrosis, as well as possible activation of co-infections such as tuberculosis, and a reported case of fatal strongyloides. ${ }^{45}$ In 2006, a severe ENL case was treated successfully with the genetically engineered biologic infliximab. ${ }^{46}$ However, infliximab is expensive, and can also reactivate infections including unmasking previously undiagnosed cases of leprosy. ${ }^{46}$

In 1964, Dr Jacob Sheskin discovered the beneficial effects of thalidomide on suppressing ENL reactions. ${ }^{47}$ From the 1970s into the 1990s, while working at Carville, Dr Robert Hastings was the leader in making thalidomide available under an investigational new drug (IND) protocol for the treatment 
of ENL in the US at a time when it was otherwise banned in the US because of its severe teratogenicity. Thalidomide has a very rapid onset of action in controlling severe ENL and reduces the need for prednisone. In the US, it is now available under the System for Thalidomide Education and Prescribing Safety (STEPS) program's stringent guidelines for use only by physicians who register with the program. ${ }^{18}$ The current WHO guidelines for the management of severe ENL include clofazimine but exclude the use of thalidomide, ${ }^{48}$ however, much remains to be learned about optimal therapies, dosages, and duration of treatment. Kahawita et al give extensive coverage of reversal reactions and their treatment in their review. ${ }^{45}$

\section{Relapses after MDT}

The long-term success of any antimicrobial therapy of an infectious disease is usually judged by eradication of the responsible infectious organism. For most human infectious diseases, this means negative culture results and clinical cure. $M$. leprae is unique in that there is no method, to date, of in vitro culturing. The WHO therefore uses a proxy approach, defining a leprosy relapse case as a patient, who successfully completes an adequate course of WHO MDT, but subsequently develops new symptoms of the disease either during the surveillance period or thereafter. ${ }^{49,50}$ The WHO further defines relapse in MB leprosy as: "the multiplication of $M$. leprae suspected by the marked increase (at least $2+$ over the previous value) in the bacterial index at any single site, usually with evidence of clinical deterioration." ${ }^{51}$ Recognition of relapse in paucibacillary leprosy is somewhat difficult as, clinically, PB relapse and PB reversal reactions can be indistinguishable. ${ }^{51}$ The WHO advises that: "In theory, a therapeutic test with corticosteroids may be able to distinguish between these two phenomena: a definite improvement within four weeks of corticosteroid therapy denoting reversal reaction, and nonresponse to corticosteroids during the same period favoring the diagnosis of clinical relapse." ${ }^{51}$ Poojabylaiah et al gave the following differential diagnosis for relapse:

The main differential diagnoses for relapse are reversal reactions, erythema nodosum leprosum and reactivation/ resistance/reinfection. The most reliable criteria for making an accurate diagnosis of relapse include clinical, bacteriological, and therapeutic criteria. Additional ones that may be used, depending on the setting, are histopathological and serologic criteria. ${ }^{48}$

The first WHO MDT guidelines, adopted in 1982, included supervised monthly rifampin and clofazimine and daily unsupervised dapsone and clofazimine given for 2 years for MB leprosy. ${ }^{52}$ However, in 1998 , WHO guidelines reduced the standard course of MDT treatment of MB disease to 1 year, and also eliminated the requirement for bacteriological assessment, including slit skin smears and histology for bacteriological assessment. ${ }^{24}$ This made followup for relapse of those diagnosed post-1998 more difficult, since some cases may have been originally misdiagnosed, ${ }^{28}$ or bacterial indices not measured.

Relapsed cases of leprosy should be identified and placed back on chemotherapy as soon as possible to prevent further disability and transmission of infection. Factors that should be considered in choosing an appropriate regimen are the type of leprosy (PB or MB), previous treatment and drug resistance. Occasionally, clinicians may need to use their judgment to modify the standard WHO treatment regimens according to the scenario in each patient. ${ }^{53}$ WHO guidelines ${ }^{35}$ are that all MB cases should be treated with standard MB-MDT without waiting for results of drug resistance studies, and that MB-MDT treatment should be continued accordingly (clofazimine $50 \mathrm{mg}$, ofloxacin $400 \mathrm{mg}$, and minocycline $100 \mathrm{mg}$ daily for 6 months) even if dapsone resistance is detected; but if rifampin-resistant $M$. leprae are present, or both dapsone and rifampin resistance are present, then this same combination of drugs (clofazimine $50 \mathrm{mg}$, ofloxacin $400 \mathrm{mg}$, and minocycline $100 \mathrm{mg}$ daily) should be continued for another 18 months or a total of 24 months.

Relapse rates post-2 year WHO MDT of MB leprosy in three prospective studies have varied from $0 \%$ to as high as $20 \%$, with the highest risk being for those who had a pre-MDT average BI of 4 or above. ${ }^{52} \mathrm{~A}$ prospective study published in 2009 showed a relapse rate cumulative risk of $6.6 \%$ in 500 MB patients, who were first enrolled between 1987 and 1994 , and were followed at a well-established leprosy referral and treatment center, Cebu City Clinic, Philippines, for 6-16 years (mean 10.5 years) post-completion of 2 years of WHO MDT, with those with a pre-MDT BI of 4 or above having a cumulative risk of $10.1 \% .{ }^{52}$ In mouse footpad assays, $M$. leprae from relapsed patients were rifampin and clofazimine sensitive, and combined with the complete data set, the results suggested that relapses were due to activation of dormant $M$. leprae (persisters) not killed by MDT, rather than new infections. ${ }^{52}$

There is a concern that, especially for patients with BIs of 4 or above, the 1998 reduction of the WHO MDT for MB leprosy from 2 years to 1 year may lead to increased numbers 
of relapses. ${ }^{37,52}$ The same may be true for PB cases whose treatment times were also reduced to 6 months in 1998 .

Methods of detecting drug resistance are being replaced by molecular detection methods of mutations in the rpoB gene for rifampin resistance, folP 1 for dapsone resistance, and gyrA for ofloxacin resistance. In a recent Brazilian study, ${ }^{54}$ 145 relapse cases were studied for MDT drug resistance through gene sequence analysis, with 92 cases having successful positive amplification of genes associated with $M$. leprae drug resistance. Of the 92 cases, four cases, (three MB cases post- 2 year MDT and one PB case post-1 year MDT) showed gene mutations suggesting drug resistance. One analysis indicated resistance to rifampin and those of three relapsed cases indicated multidrug resistance: to both dapsone and rifampin in one case, and in two cases (including the relapsed PB) mutations for three drugs: dapsone, rifampin, and ofloxacin. The median time from end of MDT to relapse was 9.45 years for all relapsed cases, but with a significantly shorter median time to relapse of 3.26 years (range: 1 month to 6.6 years) in those cases showing mutations for drug resistance. ${ }^{54}$

\section{Future directions in treatment Diffuse lepromatous leprosy and the role of $M$. lepromatosis}

Diffuse lepromatous leprosy (DLL) is a distinct manifestation of leprosy endemic in Mexico and the Caribbean, in which diffuse infiltration of the skin without tumors is observed. DLL is also seen, but rarely, throughout the world. Patients with DLL develop a reaction called Lucio's phenomenon, in which ischemic infarcts result in recurrent large, sharply marginated, ulcerative lesions - particularly on the lower extremities - that may be generalized and, when so, are frequently fatal as a result of secondary infection and consequent septic bacteremia. ${ }^{9}$ Histologically, the lesions are characterized by ischemic necrosis of the epidermis and superficial dermis, heavy parasitism of endothelial cells with acid-fast bacilli, and endothelial proliferation and thrombus formation in the larger vessels of the deeper dermis. ${ }^{55}$

Through multigene analysis a new leprosy-causing mycobacterium was recently found to be present in all DLL cases examined. Similar to M. leprae, but yet genetically distinct (9.1\% sequence difference in 20 genes and pseudogenes), the mycobacterium $M$. lepromatosis ${ }^{56}$ diverged from $M$. leprae 10 million years ago.$^{57} \mathrm{M}$. lepromatosis was also found in Mexican leprosy patients with lepromatous leprosy (that is, not manifesting as DLL), and some patients were co-infected with M. leprae..$^{58}$ Although M. lepromatosis patients have been treated with MDT and have improved, it is not clear that the treatment regimen used for M. leprae is the best one for M. lepromatosis. None of the current PCR tests for $M$. leprae detect $M$. lepromatosis. With histological diagnosis of leprosy being used less under field conditions, together with PCR-based diagnostic testing for amplifying bacterial DNA becoming more common, especially for drug susceptibility testing, cases of infection by $M$. lepromatosis may go undetected, jeopardizing patient recovery. ${ }^{59}$ Fortunately, it is possible to prepare target genes and primer sequences capable of PCR amplification to reliably identify M. lepromatosis on retest of a negative $M$. leprae PCR test result.

\section{Multidrug-resistant $M$. leprae}

The present WHO approach for eliminating leprosy is based on case detection and antimicrobial chemotherapy. The practice of unsupervised chemotherapy with attendant potential noncompliance, and unavailability of a test for drugresistant $M$. leprae on a routine basis, can cause incomplete chemotherapy that leads to relapse, reinfection, and natural selection of drug-resistant strains of M. leprae.

Under the current WHO simplified leprosy diagnostic criteria, PB overlaps the immune response-based MB RidleyJopling classification, so that for some WHO cases, infectious bacilli could remain after MDT that are enriched in drugresistant mutant $M$. leprae. In addition, clofazimine causes hyperpigmentation that some patients find objectionable, so that they discontinue the self-administered MDT. This leads to selective survival of not only dapsone-, but also rifampinresistant mutant bacilli, which are now established in some endemic areas. ${ }^{60}$ Further, there is still a social stigma caused by diagnosis of leprosy, which can affect treatment. In one Hansen's disease clinic in 2012, a patient confided that his friend was experiencing nodular swellings. To the suggestion that he tell his friend to make a clinic appointment, he responded that he did not want to run the risk that his friend might find out that he was also going to the clinic for leprosy treatment. Because of the social stigma that a diagnosis of leprosy often creates, patients infected with drug-resistant leprosy may delay seeking treatment, during which time they create more drug-resistant bacilli that can ultimately infect other people.

Finding and testing new drugs for effective treatment of leprosy is an ongoing challenge as strains of drug-resistant M. leprae inevitably emerge. A huge bottleneck in confirming 
whether a strain of $M$. leprae is drug-resistant is the prior need to carry out in vivo culturing in mice footpads, a lengthy, slow (6-12 month) process. A recent study ${ }^{61}$ of gene mutations in $M$. leprae responsible for dapsone resistance found that it is possible to functionally replace an essential gene of a fast-growing mycobacterium with various mutant dapsoneresistant $M$. leprae gene sequence counterparts, allowing in vitro culturing of the recombinant bacterium that demonstrated similar resistance to dapsone as the dapsone-resistant $M$. leprae mutations. This technique is being used to monitor $M$. leprae resistance to the MDT components rifampin and dapsone, and to the new fluoroquinolone leprosy drugs (for example, as cited above in the Brazilian study of relapse cases), ${ }^{54}$ but not to clofazimine, for which a genetic resistance mechanism has not been found. ${ }^{34}$

\section{New drug treatments}

Three US Food and Drug Administration (FDA)-approved antimicrobial drugs - moxifloxacin, gatifloxacin, and linezolid - were tested in mouse footpads for bactericidal effect against $M$. leprae. They were evaluated alone and in combination with the rifamycins - rifampicin (rifampin) and rifapentine - to simulate a MDT regimen. All three were found bactericidal against rapidly multiplying M. leprae. ${ }^{62}$

Moxifloxacin is an FDA-approved fluoroquinolone antimicrobial drug that carries a risk of tendinitis and tendon rupture, especially in those over age 60 . It is considered a drug of last resort when all other antibiotics have failed. In clinical trials for drug-resistant tuberculosis, a single dose of moxifloxacin of up to $800 \mathrm{mg}$ was tolerated well, but some patients experienced major adverse events (nausea, vomiting, muscle pain, tremors, insomnia, and dizziness) after 6 months' continual use of $400 \mathrm{mg}$ once daily. ${ }^{62}$

Gatifloxacin is a FDA-approved fluoroquinolone antibiotic that inhibits the bacterial enzymes DNA gyrase and topoisomerase IV. In clinical trials for drug-resistant tuberculosis treatment, a single dose of gatifloxacin (400 mg) was tolerated well. Patients treated with gatifloxacin at 100 to $400 \mathrm{mg} /$ day for 5 to 12 days reported only mild adverse events. ${ }^{62}$

Linezolid is a synthetic oxazolidione drug approved by the FDA to treat infections by Gram-positive bacteria. It is a protein synthesis inhibitor, stopping the growth of bacteria by disrupting their production of proteins. Long-term use (more than two weeks) can cause bone marrow suppression and low platelet counts, and continual long-term use can cause peripheral neuropathy, optic nerve damage, and lactic acidosis. In several clinical trials for drug-resistant tuberculosis, with daily linezolid doses averaging $600 \mathrm{mg}$, more than $61 \%$ of patients reported adverse events, and more than $36 \%$ discontinued linezolid due to adverse events. ${ }^{62}$

\section{Vitamin D}

In order for host-adaptive immune system T-cells to fight off infection from $M$. leprae, immature T-cells must first be exposed to traces of the foreign pathogen, which happens once they are presented by macrophages with suspicious "cell fragments" or "traces" of the bacillus. The T-cells subsequently divide and multiply into hundreds of identical cells that are all focused on the same pathogen type, leading to a targeted immune response. Professor Carsten Geisler recently found how vitamin $\mathrm{D}$ is involved in this adaptive T-cell activation: once an immature T-cell is presented with a foreign pathogen, it extends a vitamin D receptor (VDR), which searches the vicinity for vitamin $\mathrm{D}$. If vitamin $\mathrm{D}$ is present, it binds with the VDR, returns to the T-cell nucleus, and activates the gene that initiates transformation to a mature immune cell. This means that if the nascent T-cells cannot find enough vitamin D in the blood, they won't even begin to mobilize. ${ }^{63}$

T-cells that successfully activate transform into one of two types of immune cell. They either become killer cells that attack and destroy all cells carrying traces of a foreign pathogen, or they become T helper type 1 cells (Th1) that assist the immune system in acquiring "memory." The Th1 cells send messages to the immune system, passing on knowledge about the pathogen so that the immune system can recognize and remember it at their next encounter.

Recently researchers compared the micro-RNAs (miRNA) in human skin lesions from two types of leprosy, tuberculoid (T-Lep) and Lepromatous (L-Lep) (see Table 1). MiRNAs are small molecules made up of ribonucleic acids that do not code information for proteins, but rather they bind to the RNA that does code for proteins and block them. The researchers found that $M$. leprae can actually regulate the host's cellular miRNA profile at the site of the infection to interfere with the antimicrobial response. ${ }^{64}$ Human monocytes, or macrophages, infected with $M$. leprae express the miRNA, hsa-mir-21 which actually blocks the nascent T-cell's gene that would otherwise activate when vitamin D is present, preventing the transformation into Th1 cells.

With this discovery, the researchers recognized a potential therapeutic approach that doesn't rely on administering drugs toxic to $M$. leprae, but rather administering anti-hsa mir-21 to help counter the overexpression of hsa-mir-21 induced by $M$. leprae, together with vitamin $\mathrm{D}$ supplementation. ${ }^{64}$ This combination, at the proper dose, should encourage a 
strong adaptive immune response, to limit or even heal the M. leprae infection.

\section{Early diagnosis of disease}

In the past few years the number of new leprosy cases diagnosed has remained fairly stable. ${ }^{65}$ This means that disease transmission has not changed much over the past decade. Specific serological tests for screening and diagnosis are still needed. One current approach uses bioinformatics and comparative genomics to identify potentially antigenic proteins for diagnostic purposes, as well as future vaccine development. Purifying proteins derived from M. leprae, which is noncultivatable in vitro and has to be grown in association with host cells, presents a technical challenge. This approach has defined three classes of proteins: those restricted to $M$. leprae (class 1); those present in M. leprae with orthologs in other organisms besides mycobacteria (class 2); and those exported or surface-exposed proteins (class 3 ). Twelve genes (two class 1 , four class 2 , and six class 3 proteins) have been cloned in Escherichia coli, and their protein products purified. Six of these proteins have also been detected in cell extracts of $M$. leprae by immunoblotting. The immunogenicity of each recombinant protein was then investigated in leprosy patients by measuring the reactivity of circulating antibody and gamma interferon (IFN- $\gamma$ ) responses in T-cell restimulation assays. Several class 2 and class 3 proteins were recognized by circulating antibodies. Importantly, most class 2 proteins elicited IFN- $\gamma$ responses that were significantly stronger than those produced by previously identified antigens. Among them, two class 2 proteins, ML0308 and ML2498, showed marked humoral and cellular immunogenicity, therefore providing promising candidates for the diagnosis of both $\mathrm{PB}$ and MB leprosy. ${ }^{66}$ In another study, M. leprae-unique antigens, especially ML2478, were identified as biomarker candidates to measure $M$. leprae exposure using IFN- $\gamma$ or IFN-inducible protein-10, and that MCP-1, MIP-1 $\beta$, and IL- $\beta$ can possibly distinguish pathogenic immune responses in those developing leprosy, from those responses induced during asymptomatic exposure to $M$. leprae in people living in endemic areas. ${ }^{67}$

\section{Vaccines}

Bacillus Calmette-Guérin (BCG) vaccination for M. tuberculosis in early childhood is recognized as having a $50 \%$ protective effect against acquiring $M$. leprae infection in endemic areas. Although imperfect, it is still the best available vaccine for the prevention of leprosy ${ }^{68,69}$ Duthie et al reviewed multiple large-scale studies, ${ }^{69}$ finding that attempts to combine BCG with killed $M$. leprae or with components of $M$. leprae, or in combination with killed Mycobacterium vaccae, have not shown any greater protection than $\mathrm{BCG}$ vaccination alone. Although BCG vaccination protects children from $M$. leprae infection, after a few years the protection wanes and no "booster shot" to restore immunity has been found.

An ideal vaccine against leprosy would provide longlasting protection. The definition of the M. leprae genome should now allow developers of a vaccine to focus on subunit antigens that are recognized by the immune system in PB patients, and which are also known to stimulate interferon- $\gamma$ production. By using recombinant gene insertion in faster dividing bacteria to cause them to express the antigen, vaccine developers may be able to create and test a more effective vaccine than BCG specifically against leprosy.

\section{Conclusion}

In order to have complete control of leprosy or any infectious disease, the cycle of transmission must be broken in endemic areas with a highly effective vaccine. Until this happens, a simplified, accurate diagnostic test for both $M$. leprae and M. lepromatosis would help shorten the time for leprosy patients to start MDT. Educational efforts should continue to help reduce and remove the stigma associated with a leprosy diagnosis, and help reduce noncompliance with MDT that leads to drug resistance.

\section{Disclosure}

The author has no financial interest in any of the items discussed. The author reports no conflicts of interest in this work.

\section{References}

1. Robbins G, Tripathy VM, Misra VN, et al. Ancient skeletal evidence for leprosy in India (2000 B.C.). PLoS ONE. 2009;4(5):e5669.

2. Eiglmeier K, Simon S, Garnier T, Cole ST. The integrated genome map of Mycobacterium leprae. Lepr Rev. 2001;72(4):462-469.

3. Shepard CC. Temperature optimum of Mycobacterium leprae in mice. J Bacteriol. 1965;90(5):1271-1275.

4. Desikan KV, Sreevatsa. Extended studies on the viability of Mycobacterium leprae outside the human body. Lepr Rev. 1995;66(4): 287-295.

5. Portaels F, Fissette K, De Ridder K, Macedo PM, De Muynck A, Silva MT. Effects of freezing and thawing on the viability and the ultrastructure of in vivo grown mycobacteria. Int J Lepr Other Mycobact Dis. 1988;56(4):580-587.

6. Rea TH, Modlin RL. Leprosy. In: Wolff K, Goldsmith LA, Katz SI, Gilchrest BA, Paller AS, Leffell DJ, editors. Fitzpatrick's Dermatology in General Medicine. 7th ed. New York: McGraw-Hill; 2008:1786-1796.

7. Duncan ME, Melsom R, Pearson JM, Menzel S, Barnetson RS. A clinical and immunological study of four babies of mothers with lepromatous leprosy, two of whom developed leprosy in infancy. Int J Lepr Other Mycobact Dis. 1983;51(1):7-17.

8. Porrit RJ, Olsen RE. Two simultaneous cases of leprosy developing in tattoos. Am J Pathol. 1947;23:805-817. 
9. Gelber RH. Leprosy (Hansen's Disease) In: Fauci AS, Braunwald E, Kasper DL, Hauser SL, Longo DL, Jameson L, Loscalzo J, editors. Harrison's Principles of Internal Medicine. 17th ed. New York: McGraw-Hill; 2008:1021-1027.

10. Leprosy Today [webpage on the Internet]. Geneva: World Health Organization; c2011 [cited 2012 May 28]. Available from: http://www.who. int/lep/en/. Accessed February 22, 2012.

11. Levis WR, Paraskevas LR, Jacobson M, Spencer J, Spencer T, Martiniuk F. Endemic leprosy in New York City. Arch Dermatol. 2011;147(5):624-626.

12. Truman RW, Singh P, Sharma R, et al. Probable zoonotic leprosy in the southern United States. N Engl J Med. 2011;364(17):1626-1633.

13. Leprosy (Hansen's disease) [webpage on the Internet]. Victoria, Australia: Department of Health, Victoria, Australia; [updated 2007 February 10; cited 2012 May 8]. Available from: http://ideas.health.vic.gov.au/ bluebook/leprosy.asp. Accessed April 24, 2012.

14. Global Health Observatory (GHO), Leprosy [webpage on the Internet]. Geneva: World Health Organization; c2012 [cited 2012 May 28]. Available from: http://www.who.int/gho/neglected_diseases/leprosy/ en/index.html. Accessed February 12, 2012.

15. Dharmendra. Classification of leprosy. In: Hastings RC, editor. Leprosy. Edinburgh: Churchill-Livingstone; 1985:88-99.

16. Skacel M, Antunes SL, Rodrigues MM, et al. The diagnosis of leprosy among patients with symptoms of peripheral neuropathy without cutaneous lesions: a follow-up study. Arq Neuropsiquiatr. 2000;58 (3B):800-807.

17. Scollard DM, Adams LB, Gillis TP, Krahenbuhl JL, Truman RW, Williams DL. The continuing challenges of leprosy. Clin Microbiol Rev. 2006;19(2):338-381.

18. Worobec SM. Treatment of leprosy/Hansen's disease in the early 21 st century. Dermatol Ther. 2009;22(6):518-537.

19. Meyers WM. Mycobacterial Infections of the Skin: B. Leprosy: I. Introduction and Epidemiology. In: Ashworth TG, editor. Tropical Pathology. 2nd ed. New York: Springer; 1995:294-296.

20. Moschella SL. An update on the diagnosis and treatment of leprosy. J Am Acad Dermatol. 2004;51(3):417-426.

21. Ridley DS, Jopling WH. Classification of leprosy according to immunity. A five-group system. Int J Lepr Other Mycobact Dis. 1966;34(3):255-273.

22. Ridley DS, Jopling WH. A classification of leprosy for research purposes. Lepr Rev. 1962;33:119-128.

23. Jayalakshmi MBBS. Histopathology of skin lesions in leprosy. Malaysian J Pathol. 1980;3:39-45.

24. Lockwood DN. Leprosy elimination-a virtual phenomenon or a reality? BMJ. 2002;324(7352):1516-1518.

25. Diagnosis of leprosy [webpage on the Internet]. Geneva: World Health Organization; c2012 [cited 2012 May 28]. Available from: http://www. who.int/lep/diagnosis/en/. Accessed February 24, 2012.

26. The "Final Push" strategy for elimination [webpage on the Internet]. Geneva: World Health Organization; c2012 [cited 2012 May 28]. Available from: http://www.who.int/lep/strategy/en/. Accessed April 25, 2012.

27. WHO Model Prescribing Information: Drugs Used in Leprosy [webpage on the Internet]. Geneva: World Health Organization; c2012 [cited 2012 May 28]. Available from: http://apps.who.int/medicinedocs/en/d/ Jh2988e/4.html\#Jh2988e.4. Accessed April 24, 2012.

28. Ebenezer GJ, Suneetha S, Mohandas R, Arunthathi S. Multibacillary nerve histology in clinically diagnosed borderline tuberculoid leprosy patients. Int J Lepr Other Mycobact Dis. 1996;64(3):311-315.

29. WHO roadmap inspires unprecedented support to defeat neglected tropical diseases [webpage on the Internet]. Geneva: World Health Organization; c2012 [cited 2012 May 28]. Available from: http://www.who.int/neglected_ diseases/London_meeting_follow_up/en/. Accessed March 12, 2012.

30. Monot M, Honoré N, Garnier T, et al. Comparative genomic and phylogeographic analysis of Mycobacterium leprae. Nat Genet. 2009;41(12):1282-1289.

31. Williams DL, Pittman TL, Deshotel M, Oby-Robinson S, Smith I, Husson R. Molecular basis of the defective heat stress response in Mycobacterium leprae. J Bacteriol. 2007;189(24):8818-8827.
32. Gulia A, Fried I, Massone C. New insights in the pathogenesis and genetics of leprosy. F1000 Med Rep. 2010;2.

33. History of the National Hansen's Disease (Leprosy) Program [webpage on the Internet]. U.S. Department of Health and Human Services: Health Resources and Services Administration. Available from: http://www.hrsa.gov/hansensdisease/history.html. Accessed 18 June, 2012.

34. Williams DL, Gillis TP. Molecular detection of drug resistance in Mycobacterium leprae. Lepr Rev. 2004;75(2):118-130.

35. Guidelines for Global Surveillance of Drug Resistance in Leprosy [webpage on the Internet]. Geneva: World Health Organization; c2012 [cited 2012 May 28]. Available from: http://www.searo.who. int/catalogue/2005-2011/leprosy.htm. Accessed April 29, 2012.

36. Singh P, Cole ST. Mycobacterium leprae: genes, pseudogenes and genetic diversity. Future Microbiol. 2011;6(1):57-71.

37. James WD, Berger TG, Elston DM. Hansen's Disease. In: James WD, Berger TG ,Elston DM, editors. Andrews' Diseases of the Skin: Clinical Dermatology. 11th ed. Philadelphia: Saunders Elsevier; 2011: 334-344.

38. Kumar B, Dogra S. Leprosy. In: Rakel RE, Bope ET, editors. Conn's Current Therapy 2009. Philadelphia: Elsevier Health Sciences; 2008:97- 103 .

39. WHO recommended MDT regimens [webpage on the Internet]. Geneva: World Health Organization; c2012 [cited 2012 May 28]. Available from: http://www.who.int/lep/mdt/regimens/en/. Accessed February 28, 2012.

40. Fischer JH, West DP, Worobec SM. Evaluation of a continual compliance monitoring program for dapsone in an outpatient Hansen's disease clinic. Int J Lepr Other Mycobact Dis. 1986;54(4): 517-524.

41. Deps PD, Nasser S, Guerra P, Simon M, Birshner Rde C, Rodrigues LC. Adverse effects from multi-drug therapy in leprosy: a Brazilian study. Lepr Rev. 2007;78(3):216-222.

42. Recommended Treatment Regimens [webpage on the Internet]. Rockville: US Department of Health and Human Services; [cited 2012 May 28]. Available from: http://www.hrsa.gov/hansensdisease/ diagnosis/recommendedtreatment.html. Accessed March 6, 2012.

43. ILEP. Early Detection and treatment of reversal reaction under field conditions. ILEP Technical Bulletin [serial on the Internet]. 2011 Apr [cited 2012 May 28];12:[about 3 p]. Available from: http://www.ilep. org.uk/fileadmin/uploads/Documents/Technical_Bulletins/tb12eng.pdf. Accessed May 28, 2012.

44. Legendre DP, Muzny CA, Swiatlo E. Hansen's disease (Leprosy): current and future pharmacotherapy and treatment of diseaserelated immunologic reactions. Pharmacotherapy. 2012;32(1): $27-37$.

45. Kahawita IP, Walker SL, Lockwood DN. Leprosy type 1 reactions and erythema nodosum leprosum. An Bras Dermatol. 2008;83(1): $75-82$.

46. Faber WR, Jensema AJ, Goldschmidt WF. Treatment of recurrent erythema nodosum leprosum with infliximab. $N$ Engl $J$ Med. 2006;355(7):739.

47. Greenstone G. The revival of thalidomide: From tragedy to therapy; BC Medical J. 2011;53(5):230-233.

48. Use of clofazimine for treating ENL reactions in leprosy. WHO Guide to the management of ENL reactions [webpage on the Internet]. Geneva: World Health Organization; c2012 [cited 2012 May 28]. Available from: http://www. who.int/lep/mdt/clofazimine/en/index.html. Accessed February 12, 2012.

49. Poojabylaiah M, Marne RB, Varikkodan R, Bala N, Dandakeri S, Martis J. Relapses in multibacillary leprosy patients after multidrug therapy. Lepr Rev. 2008;79(3):320324.

50. A Guide to Leprosy Control. 2nd ed. Geneva: World Health Organization; 1988;40. Available from: http://whqlibdoc.who.int/publications/1988/9241542233_(part1).pdf. Accessed February 24, 2012.

51. www.who.int [homepage on the Internet]. MDT: relapse after treatment. FAQ. Geneva: World Health Organization; c2012 [cited 2012 May 28]. Available from: http://www.who.int/lep/mdt/relapse/en/index.html. Accessed April 28, 2012. 
52. Balagon MF, Cellona RV, Cruz E, et al. Long-term relapse risk of multibacillary leprosy after complision of 2 years of multiple drug therapy (WHO-MDT) in Cebu, Philippines. Am J Trop Med Hyg. 2009;81(5):895-899.

53. Kaimal S, Thappa DM. Relapse in Leprosy. Indian J Dermatol Venereol Leprol. 2009;75(2):126-135.

54. Rocha Ada S, Cunha MD, Diniz LM, et al. Drug and multidrug resistance among Mycobacterium leprae isolates from Brazilian relapsed leprosy patients. J Clin Microbiol. 2012;50(6):1912-1917.

55. Gelber RH. Leprosy (Hansen's Disease). In: Fauci AS, Braunwald E, Kasper DL, et al. Harrison's Principles of Internal Medicine. 17th ed. New York: McGraw-Hill; 2008.

56. Han XY, Seo YH, Sizer KC, et al. A new Mycobacterium species causing diffuse lepromatous leproy. Am J Clin Pathol. 2008;130(6):856-864.

57. Han XY, Sizer KC, Thompson EJ, et al. Comparative sequence analysis of Mycobacterium leprae and the new leprosy-causing Mycobacterium lepromatosis. J Bacteriol. 2009;191(19):6067-6074.

58. Han XY, Sizer KC, Tan HH. Identification of the leprosy agent Mycobacterium lepromatosis in Singapore. J Drugs Dermatol. 2012;11(2):168-172.

59. Vera-Cabrera 1, Escalante-Fuentes WG, Gomez-Flores M, et al. Case of diffuse lepromatous leprosy associated with "Mycobacterium lepromatosis". J Clin Microbiol. 2011;49(12):4366-4368.

60. Matsuoka M, Budiawan T, Aye KS, et al. The frequency of drug resistance mutations in Mycobacterium leprae isolates in untreated and replapsed leprosy patients from Myanmar, Indonesia and the Phillipines. Lepr Rev. 2007;78(4):343-352.
61. Nakata N, Kai M, Makino M. Mutation analysis of the Mycobacterium leprae folP1 gene and dapsone resistance. Antimicrob Agents Chemother. 2011;55(2):762-766.

62. Burgos J, de la Cruz E, Paredes R, Andaya CR, Gelber RH. The activity of several newer antimicrobials against logarithmically multiplying M. leprae in mice. Lepr Rev. 2011;82(3):253-258.

63. von Essen MR, Kongsbak M, Schjerling P, Olgaard K, Odum N, Geisler C. Vitamin D controls $\mathrm{T}$ cell antigen receptor signaling and activation of human T cells. Nat Immunol. 2010 Apr;11(4):344-349. Epub 2010 Mar 7.

64. Liu PT, Wheelwright M, Teles R, et al. MicroRNA-21 targets the vitamin D-dependent antimicrobial pathway in leprosy. Nat Med. 2012;18(2):267-273.

65. Global leprosy situation, 2010. Wkly Epidemiol Rec. 2010;85(35); 337-348.

66. Aráoz R, Honoré N, Cho S, et al. Antigen discovery: a postgenomic approach to leprosy diagnosis. Infect Immun. 2006;74(1):175182.

67. Geluk A, Bobosha K, van der Ploeg-van Schip JJ, et al. New biomarkers with revelance to leprosy diagnosis applicable in areas hyperendemic for leprosy. J Immunol. 2012;188(10):4782-4791.

68. Kerr-Pontes LR, Barreto ML, Evangelista CM, Rodrigues LC, Heukelbach J, Feldmeier H. Socioeconomic, environmental, and behavioura risk factors for leprosy in North-east Brazil: results of a case-control study. Int J Epidemiol. 2006;35(4);994-1000.

69. Duthie MS, Gillis TP, Reed SG. Advances and hurdles on the way toward a leprosy vaccine. Hum Vaccin. 2011;7(11):1172-1183.
Research and Reports in Tropical Medicine

\section{Publish your work in this journal}

Research and Reports in Tropical Medicine is an international, peerreviewed, open access journal publishing original research, case reports, editorials, reviews and commentaries on all areas of tropical medicine, including: Diseases and medicine in tropical regions; Entomology; Epidemiology; Health economics issues; Infectious disease; Laboratory

\section{Dovepress}

science and new technology in tropical medicine; Parasitology; Public health medicine/health care policy in tropical regions; and Microbiology. The manuscript management system is completely online and includes a very quick and fair peer-review system. Visit http://www.dovepress. com/testimonials.php to read real quotes from published authors. 